\title{
Bioactive Compounds from Vine Shoots, Grape Stalks, and Wine Lees: Their Potential Use in Agro-Food Chains
}

\author{
Marica Troilo $^{1}$, Graziana Difonzo ${ }^{1}$ (D), Vito M. Paradiso ${ }^{2}\left(\mathbb{D}\right.$, Carmine Summo $^{1}$ (D) and Francesco Caponio ${ }^{1, *}$ (D) \\ 1 Department of Soil, Plant and Food Sciences, Food Science and Technology Unit, University of Bari Aldo \\ Moro, Via Amendola, 165/ A, I-70126 Bari, Italy; marica.troilo@uniba.it (M.T.); \\ graziana.difonzo@uniba.it (G.D.); carmine.summo@uniba.it (C.S.) \\ 2 Department of Biological and Environmental Sciences and Technologies, University of Salento, S.P. 6, \\ Lecce-Monteroni, I-73100 Lecce, Italy; vito.paradiso@unisalento.it \\ * Correspondence: francesco.caponio@uniba.it
}

Citation: Troilo, M.; Difonzo, G.; Paradiso, V.M.; Summo, C.; Caponio, F. Bioactive Compounds from Vine Shoots, Grape Stalks, and Wine Lees: Their Potential Use in Agro-Food Chains. Foods 2021, 10, 342. https:// doi.org/doi:10.3390/foods10020342

Academic Editor: Vladimiro Cardenia Received: 19 December 2020

Accepted: 1 February 2021

Published: 5 February 202

Publisher's Note: MDPI stays neutral with regard to jurisdictional claims in published maps and institutional affiliations.

Copyright: (c) 2021 by the authors. Licensee MDPI, Basel, Switzerland. This article is an open access article distributed under the terms and conditions of the Creative Commons Attribution (CC BY) license (https:// creativecommons.org/licenses/by/ $4.0 /)$.

\begin{abstract}
The winemaking sector is one of the most productive worldwide, and thus it also generates large amounts of by-products with high environmental impacts. Furthermore, global market trends and government regulations promote industrial alternatives based on sustainable production processes. As a result, several studies have focused their attention on the reuse of grape by-products in the agro-food chain. Vine shoots, grape stalks, and wine lees, although produced to a lesser extent than grape pomace, have increasingly been receiving attention for their applications in the food sector, since they are a good source of functional and bioactive compounds. In this framework, our review highlights the promising results obtained by exploiting the antioxidant and/or antimicrobial activity of vine shoots, grape stalks, and wine lees or their extracts to replace the most common oenological additives and to assay the activity against food pathogens. Further, innovative functional foods and sustainable food packaging have been formulated by taking advantage of polyphenols and fiber, as well as plant bio-stimulants, in order to obtain grapes and wines with high quality characteristics. Overall, these by-products showed the potential to be recycled into the food chain as functional additives for different products and applications, supporting the sustainability of the winemaking sector.
\end{abstract}

Keywords: winery by-products; bioactive compounds; dietary fiber; polyphenols; natural additives

\section{Introduction}

Grape is one of the largest fruit crops in the world, and according to the International Organization of Vine and Wine (OIV), in 2019 the world grape production was of 77.8 million tons, of which $57 \%$ was wine grapes, $36 \%$ was table grapes, and $7 \%$ was destined for the production of dried grapes [1]. Winemaking is one of the main agro-industrial activities in the world, and Vitis vinifera L. is the most used for industrial wine production [2-4]. According to estimates by the OIV, wine production in 2020 will reach 258 million hectoliters, with Europe as the main wine producer, followed by America and Asia. Among the main wine producers, Italy is the world leader, with production of about 49 million hectoliters, followed by France and Spain [5].

Winemaking produces a large quantity of wastes and by-products in a short period of time [6], corresponding to approximately 30\% $w / w$ of the starting grapes [7-9], represented by grape pomace, grape seeds, grape stalks, and wine lees, as well as wastewater [3,6,10-12]. These by-products are considered to be highly polluting due to the presence of organic substances, $\mathrm{pH}$, salinity, and heavy metal content, thus having negative repercussions on environmental and economic sustainability [2,9,12-14].

Grape pomace is the solid residue obtained following the pressing and the fermentation process $[10,15,16]$ and represents $20-25 \%(w / w)$ of the total weight of the grape used for wine production and consists mainly of skin, pulp, stalk residuals, and seeds [10,11,17-19]. 
Traditionally grape pomace is used to produce feed, fertilizer, or different types of distillates $[16,20-23]$. However, in recent years, due to its chemical composition, grape pomace was considered a promising alternative to obtain high value added products [22]. Seeds are rich in antioxidant compounds, such as vitamin E [3] and phenolic compounds, phytosterols, fibers, proteins, carbohydrates, and minerals, but especially in lipids. Grape skin and pulp, instead, are a rich source of fibers and phenolic compounds including protocatechuic, gallic, vanillic, and caftaric acid; flavonols such as quercetin, myricetin, and kaempferol; and anthocyanins, whose presence is closely dependent on the vinification procedures and grape variety considered [24-27].

As already reported, winemaking also generates grape stalks, following destemming, and wine lees, the residue that forms after wine fermentation at the bottom of recipients. Grape stalks (about $7 \%, w / w$ of grape total weight) are usually removed before the fermentation phase to avoid excessive wine astringency [12,28]; they are a source of phenolic compounds such as tannins, flavan-3-ols, hydroxycinnamic acids, monomeric and oligomeric flavonols, and stilbenes [28,29], and lignocellulosic compounds such as hemicellulose, cellulose, and lignin $[2,9,30]$. Wine lees (about $5 \%, w / w$ of grape total weight), instead, contain mainly ethanol, tartaric acid, phenolic compounds, and yeast cells $[15,23,31]$.

In addition, the agronomic practice of pruning generates an enormous quantity of agricultural wastes, principally vine shoots, with a production estimated per year of about 1-2 tons per hectare [32]. They are usually shredded and used as a soil conditioner, to improve fertility, or as biomass to produce energy. More recently, they have been used as a source of bioactive compounds (dietary fibers, phenols, proteins, lipids, hydrocolloids) for food, pharmaceutical and cosmetic industries, due to the nutritional benefits [15,23]; while grape leaves, due to their presence of organic acids, lipids, and polyphenols, can be used in the cosmetics industry [12].

Vine shoots, grape stalks, and wine lees, although produced in smaller quantities than grape pomace, represent a rich source of functional compounds. In this framework, the purpose of this review is therefore to highlight the potential use of these wastes and byproducts in the food sector as (i) antimicrobial and antioxidant agents; ii) natural additives; (iii) nutritional and food quality improver; and (iv) filler in food packaging formulations.

\section{Health and Preservative Properties of the Bioactive Compounds}

The increasing attention paid to human health has led researchers towards the recovery and the identification of bioactive compounds in vegetable matrices, such as byproducts. These bioactive compounds are mainly represented by polyphenols-secondary metabolites produced by plants under stress conditions and involved in the defense against pathogens, environmental stress, and ultraviolet radiation $[3,28]$ — and by dietary fiber, defined as carbohydrate polymers with 10 or more monomeric units that are not hydrolyzed by the endogenous enzymes in the small intestine of humans [33] (Figure 1).

With regard to winery by-products, four main categories of polyphenols have been identified: (i) phenolic acids, present in the form of hydroxybenzoic and hydroxycinnamic acids [10,21]; (ii) flavonoids, divided into different classes, namely flavones, flavanons, flavonols, isoflavones, anthocyanins, and proanthocyanidine [22]; (iii) tannins; and (iv) stilbenes, mainly represented by trans-resveratrol and $\varepsilon$-viniferina $[18,28,34,35]$. Numerous studies have highlighted the beneficial effects of phenolic compounds, which exert antimutagenic, anticarcinogenic, anti-inflammatory, and antioxidant activity $[18,21]$. Specifically, trans-resveratrol, catechin, epicatechin, quercetin, and phenolic acids have been studied for involvement in the prevention of cardiovascular diseases, cancer, diabetes, osteoporosis, and neurodegenerative diseases [28]. In particular, they are involved in the reduction of low-density lipoproteins (LDL) [3,36,37], the consequent increase of highdensity lipoproteins (HDL), and the prevention of platelet aggregation [28]. Grape phenolic compounds promote vasodilation [35], reduce urinary F2-isoprostanes and other oxidative 
stress markers, and increase the serum oxygen radical absorbance capacity, thus decreasing the oxidation of plasma proteins in healthy and sick patients [36].

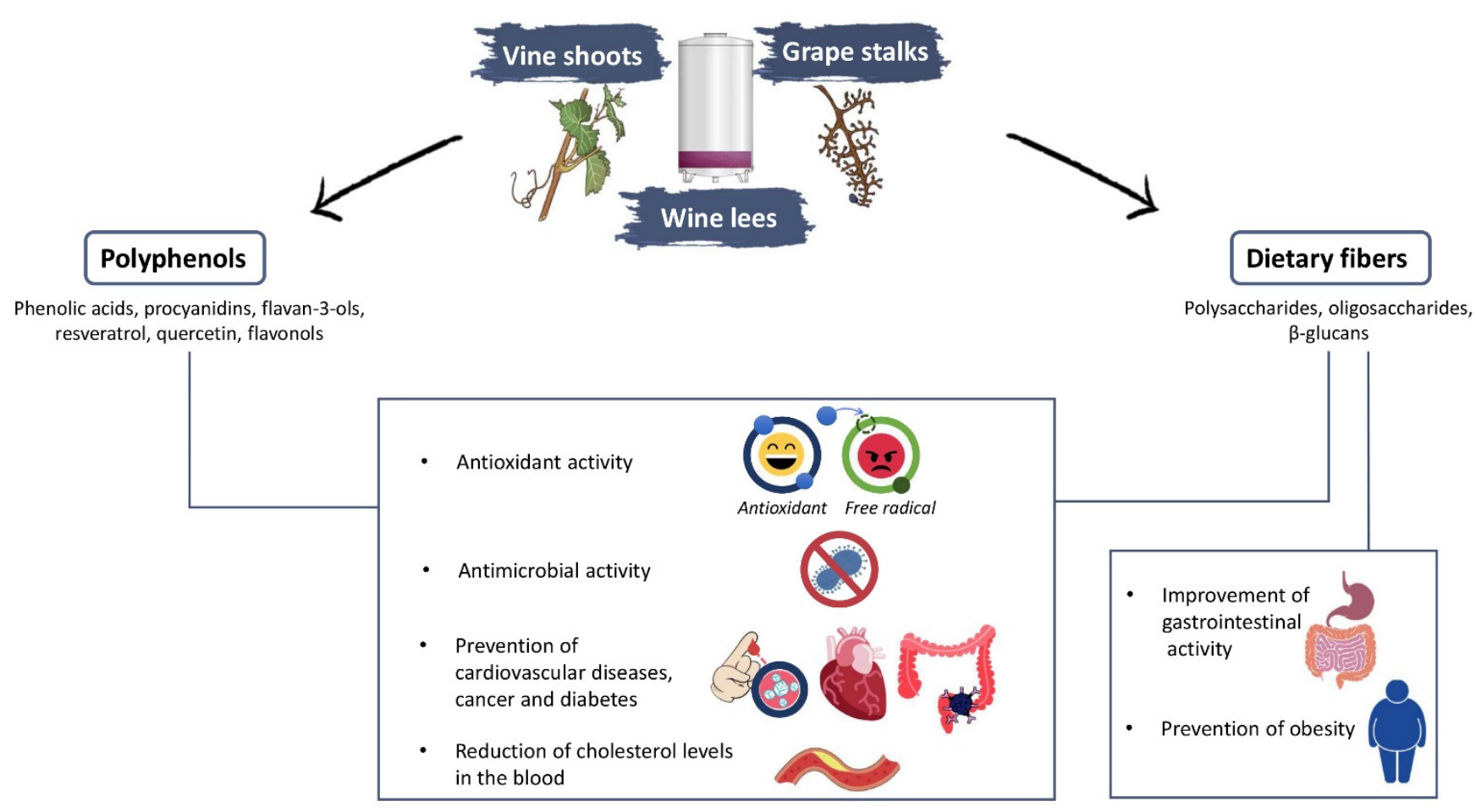

Figure 1. Effects of phenolic compounds and dietary fiber on health.

In addition, an important role for human health is also played by dietary fiber, the recommended consumption of which is about $25-30 \mathrm{~g}$ per day [38], which is generally taken as a result of the ingestion of cereals, fruits, and vegetables. Due to modern dietary habits, this value is difficult to achieve; for this reason, it is necessary to take alternative sources of dietary fiber to achieve the recommended daily amount. An adequate fiber intake is associated with the prevention of cardiovascular diseases, hypertension, diabetes, and obesity $[21,39,40]$. Further, one of the main benefits is the improvement of gastrointestinal activity in terms of motility, by modulating gastrointestinal transit time, the fecal weight, and the fecal acidity [41], followed by satiety promotion and modulation of the immune responses of the intestinal mucosa [18]. Dietary fiber can also reduce glycemic responses and cholesterol levels in the blood [41], delaying and interfering in the absorption of cholesterol and bile acids [21], but also by limiting the carbohydrate absorption, thus reducing insulin response and triacylglycerol levels, which are risk factors for coronary heart disease [39]. Some researchers showed a positive effect, due to the intake of foods containing dietary fiber and polyphenols, on the chemo preventive effects on intestinal tumorigenesis [42,43].

Dietary fiber, as well as polyphenols, can also exert antioxidant and antimicrobial action. In the food sector, microbial activity and lipid oxidation are the first indices of food spoilage, which gives rise to concerns for the food industry and for consumers [44].

Lipid oxidation is one of the main factors linked to oxidative rancidity, the loss of essential fatty acids, and the development of unpleasant flavor and smells [22]. The antioxidant activity of polyphenols is exerted by free radical inactivation, electron transfer, and scavenging and neutralizing reactive oxygen species (ROS), stopping the oxidation propagation phase and preventing the formation of peroxides [22]. They can also delay the oxidation process by acting as metal chelators to convert hydroperoxides or metal pro-oxidants into stable compounds [45-47].

The antimicrobial capacity exerted by polyphenols is frequently associated with mechanisms of depolarization and permeability of cell membranes, the decrease of bacterial proteins and loss of cytoplasm, inhibition of extracellular microbial enzymes, direct action 
on microbial metabolism, saturation of action sites, inhibition of nucleic acid synthesis, and deprivation of substrates necessary for bacterial growth through a chelation mechanism in the presence of metals $[28,46,48,49]$. Further studies highlighted the involvement of polyphenols and dietary fiber in the inhibition of pathogens such as Staphylococcus aureus, Bacillus cereus, Salmonella, Escherichia coli [22,50-53], and Listeria innocua ATCC 51142, demonstrating potential applications to preserve foods and prolong their shelf-life [41].

Besides antimicrobial and antioxidant action, the addition of oenological by-products also seems to influence the qualitative and organoleptic characteristics of fortified products with a significant impact on the phenolic and volatile component, and on color, texture, and sensory characteristics. Many reviews in the literature, in fact, underline the growing interest of researchers in the bioactive compounds present in grape pomace and seed, and their effects not only on human health, but also on food properties $[16,18,21,22,41,54]$.

\section{Food Applications}

The remarkable amount of winemaking sector by-products has led researchers to look for alternative uses to enhance them. In Table 1 are reported the possible applications of grape stalks, vine shoots, and wine lees as food ingredients to ensure or improve some qualitative characteristics of foods, such as wine and ice cream, acting as antioxidants and antimicrobials, and/or increasing their nutritional value, being a source of fiber.

\subsection{Substitution of Sulfur Dioxide in Winemaking}

Sulfur dioxide $\left(\mathrm{SO}_{2}\right)$ is one of the most used additives in the winemaking industry, due to its antioxidant and antimicrobial activity. In fact, it is used to control unwanted microorganisms and enzymatic activities during winemaking, controlling oxidative processes and unwanted fermentations [56,78]. However, its excessive use is associated with adverse effects on human health related to dermatitis, urticaria, bronchoconstriction, and anaphylaxis; and defects related to organoleptic alterations, such as neutralization of aromatic compounds and the appearance of defects in wine, increasing unpleasant flavors and smells, and increasing turbidity $[60,78]$. For this reason, there is great interest in replacing or limiting the levels of $\mathrm{SO}_{2}$ added in wines, and among the most used methods are high pressure, ultrasound, and pulsed electric fields, which exert only the antimicrobial effect but not the antioxidant activity $[56,60]$. Therefore, the addition of natural compounds, including lysozyme, hydroxytyrosol, oenological tannins, and plant extracts has been tested $[55,79]$. In recent years, there is a growing tendency to use wine by-products, such as grape stalks and vine shoots-due to the presence of phenolic acids (caffeic acid, gallic and p-coumaric acid), flavonoids (catechin, epicatechin, and luteolin), and stilbenes (trans-resveratrol and its trans- $\varepsilon$-viniferin dimer)-to replace $\mathrm{SO}_{2}$, thus acting as natural antioxidants and stabilizers of wine, contrasting the formation of aggregates between proteins and $\mathrm{SO}_{2}$, the cause of opacity and instability [80-86]. 
Table 1. Applications of vine shoots, grape stalks, and wine lees or their extracts in food and beverages.

\begin{tabular}{|c|c|c|c|c|c|}
\hline Aims & Compounds & Treatment & Source & Result & References \\
\hline \multirow{8}{*}{$\mathrm{SO}_{2}$ substitution in wine } & & Hydroalcoholic extraction & GS & Increased antioxidant and antimicrobial activity in wine model. & [55] \\
\hline & & & VS & $\begin{array}{l}\text { Improvement of color intensity and sensory characteristics until } 12 \text { months of storage. } \\
\text { Improvement of color intensity phenolic compounds and auality of wine }\end{array}$ & [56] \\
\hline & Stilbenes & & ve & $\begin{array}{l}\text { Improvement of color intensity, phenolic compounds, and quality of wine. } \\
\text { Stabilization of anthocyins and improvement of the chromatic properties of wine, polvphenol stabilization and }\end{array}$ & [57] \\
\hline & & & VS & $\begin{array}{l}\text { Stabilization of anthocyanins and improvement of the chromatic properties of wine, polyphenol stabilization and } \\
\text { aromatic profile of wine. }\end{array}$ & [58] \\
\hline & \multirow{4}{*}{$\begin{array}{l}\text { Phenolic acids, } \\
\text { flavanols and tannins }\end{array}$} & \multirow{4}{*}{$\begin{array}{l}\text { Aqueous extraction } \\
-- \\
\text { Toasting and untoasting } \\
\text { chips and granules }\end{array}$} & GS & $\begin{array}{l}\text { Increase of antioxidant and antimicrobial activity in treated wines; increase attributes related to floral and fruity } \\
\text { aroma. }\end{array}$ & [60] \\
\hline & & & GS & Increase of phenolic compounds, astringency, and bitterness and decrease of color intensity. & [61] \\
\hline & & & vs & Positive modification of flavor of model wine. & [62] \\
\hline & & & VS & Improvement of chemical composition of wines in terms of phenolic substances and antioxidants. & [63] \\
\hline \multirow[t]{4}{*}{ Improvement of wine quality } & \multirow[t]{4}{*}{ Phenolic compounds } & \multirow[t]{3}{*}{ Aqueous extraction } & VS & \multirow{4}{*}{$\begin{array}{l}\text { Increase of content of amino acids in must, and volatile composition of the wines. } \\
\text { Improvement of wine quality in terms of pH, total acidity, volatile acidity, intensity of color, aroma, and volatile } \\
\text { and phenolic compounds. } \\
\text { Improvement of white wine quality in terms of aromatic profile and phenolic compounds. } \\
\text { Increase of phenolic compounds and preservation of glutathione content. } \\
\text { Improvement of antioxidant activity and phenolic content of wines and increase of herbal notes in taste and flavor. }\end{array}$} & [65] \\
\hline & & & vs & & [66] \\
\hline & & & $\begin{array}{l}\text { VS } \\
\text { VS }\end{array}$ & & {$[32]$} \\
\hline & & Raw sample & GS & & [68] \\
\hline $\begin{array}{l}\text { Production of grape } \\
\text { stem-based liqueur }\end{array}$ & Phenolic compounds & Crushing & GS & $\begin{array}{l}\text { Improvement of phenolic compound, antioxidant activity, and intensity of color of liqueur after } 90 \text { days of } \\
\text { maceration. }\end{array}$ & [69] \\
\hline $\begin{array}{l}\text { Production of fortified } \\
\text { cereal bar }\end{array}$ & Protein & $\begin{array}{l}\text { Drying, crushing, and } \\
\text { autolysis }\end{array}$ & WL & Improvement of protein content of cereal bars; small difference in color and taste. & [70] \\
\hline \multirow{3}{*}{$\begin{array}{l}\text { Production of high-added } \\
\text { value ice cream }\end{array}$} & \multirow{3}{*}{$\begin{array}{l}\text { Phenolic compounds } \\
\text { and dietary fiber }\end{array}$} & \multirow{3}{*}{$\begin{array}{l}\text { Homogenization with water } \\
\text { Freeze-drying and } \\
\text { homogenization with water }\end{array}$} & WL & Increase of phenolic content and improvement of physical, functional, and rheological properties. & [72] \\
\hline & & & WL & $\begin{array}{l}\text { Improvement of the physical-chemical, rheological, and sensory properties of ice cream. } \\
\text { Inem }\end{array}$ & [73] \\
\hline & & & WL & $\begin{array}{l}\text { Production of ice cream with physical-chemical and sensory properties comparable to control ice cream; increase } \\
\text { of survival rate of Lactobacillus acidophilus during } 60 \text { days of storage. }\end{array}$ & [74] \\
\hline $\begin{array}{c}\text { Synthetic additives } \\
\text { substitution in hamburger }\end{array}$ & Phenolic compounds & Freeze-drying & WL & Increase of antioxidant and antimicrobic activity and phenolic compounds in burger. & [75] \\
\hline \multirow[t]{3}{*}{ Inhibition of food pathogens } & \multirow[t]{3}{*}{ Phenolic compounds } & \multirow[t]{3}{*}{$\begin{array}{l}\text { Freeze-drying and } \\
\text { hydroalcoholic extraction }\end{array}$} & GS & $\begin{array}{l}\text { Inhibition of Listeria monocytogenes, Staphylococcus aureus, Salmonella enterica subsp. enterica serovar Typhimurium, } \\
\text { and Escherichia coli } \mathrm{O} 157: \mathrm{H} \text { in lettuce and spinach. }\end{array}$ & [76] \\
\hline & & & GS & $\begin{array}{l}\text { Reduction of adhesion potential and Listeria monocytogenes motility on food contact surfaces (steel and } \\
\text { polvpropylene). }\end{array}$ & [77] \\
\hline & & & GS & High antimicrobial activity, after 64 days of storage, against gram+ and gram - bacteria. & [49] \\
\hline
\end{tabular}

GS, grape stalks; VS, vine shoots; WL, wine lees. 


\subsubsection{Stilbenes}

Grape stalks extract rich in stilbenes was added by Ruiz-Moreno et al. [55] in amounts of 50 and $80 \mathrm{mg} / \mathrm{L}$ in a model wine in order to both reduce the $\mathrm{SO}_{2}$ in winemaking and study the effect on the aroma. The results showed a higher antioxidant effect, a lower antimicrobial effect against Saccharomyces cerevisiae and Hanseniaspora uvarum, and a higher antimicrobial effect again Candida stellata and Botryotinia fuckeliana compared to $\mathrm{SO}_{2}$. The olfactometric profile evaluated by the gas chromatography-olfactometry technique, instead, was similar to the typical one of wines. Raposo et al. [56], instead, used a commercial extract of stilbenes obtained from vine shoots in order to preserve the quality of a red wine, studying the effectiveness at bottling and the storage in bottle for twelve months. The addition, in an amount of $86 \mathrm{mg} / \mathrm{L}$ of wine $(25 \mathrm{mg} / \mathrm{L}$ of total stilbenes), increased the intensity and purity of the color and led to a high score at sensory analysis, evaluated at bottling. Moreover, the use of commercial stilbenes improved the aroma of wines and preserved volatile compounds, showing more notes of black and mature fruit. However, after aging, the extract did not allow the quality to be preserved compared to wines treated with $\mathrm{SO}_{2}$. Based on these results, in subsequent research the authors evaluated the optimal dose to increase the qualitative parameters and the sensory attributes, at two concentrations of added extract, namely $175 \mathrm{mg} / \mathrm{L}$ of wine $(50 \mathrm{mg} / \mathrm{L}$ of the total stilbene content) and $430 \mathrm{mg} / \mathrm{L}$ (100 mg/L of the total stilbene content), during twelve months of storage in bottle. The obtained results were similar to the $\mathrm{SO}_{2}$-treated wines, but with differences in phenolic composition and color intensity. The wines obtained, in fact, had high concentrations of vinyl-pyranoanthocyanins and B-type vitisins, two stable color compounds resistant to oxidation, and a lower concentration of free anthocyanins. Moreover, the addition of extract led to the modification of sensory attributes related to black fruit, caramel, and woody when $430 \mathrm{mg} / \mathrm{L}$ of extract was used, which also led to a decrease of scores related to global quality. The same quantities tested by Ruiz-Moreno et al. [58] preserved phenolic compounds and improved the chromatic characteristics of wines and did not adversely affect the aromatic composition and sensory properties, showing high concentrations of $\beta$-damascenone, an odorant associated with descriptors such as fruity, honey, and baked apple, and slight astringent notes. In the same way, Cruz et al. [59] reported that quantities of $138 \mathrm{mg} / \mathrm{L}$ of commercial stilbenes, added in white wines at bottling, positively influenced the sensorial characteristics, identifying white fruit attributes and higher aromatic intensity, without any defects, despite slight negative effects on color, until six months of storage.

\subsubsection{Phenolic Acids, Flavanols, and Tannins}

The effect of the use of extracts from grape seeds and stalks alone or in combination with colloidal silver complex was evaluated by assaying the antioxidant and antimicrobial activity and determining color, phenolic and volatile composition, and sensorial profile of white wines [60]. Wines treated with extracts of grape stalks rich in hydroxycinnamic acids, catechin, epicatechin, and procyanidin B1 and B2 showed no differences in terms of antioxidant activity and total yeasts, and lactic and acetic bacteria counts with respect to the wine treated with $\mathrm{SO}_{2}$. The chromatic parameters were increased by the addition of $0.5 \mathrm{~g} / \mathrm{L}$ of grape stalk extract, and $0.5 \mathrm{~g} / \mathrm{L}$ of grape stalk extract and $1 \mathrm{~g} / \mathrm{L}$ of colloidal silver complex; while from a microbiological point of view, no differences were found compared to control wines (treated with $\mathrm{SO}_{2}$ ). On the other hand, the phenolic and volatile composition of wines was modified using extracts, showing higher quantities of flavonols and ethyl esters and lower concentrations of acetaldehyde. In addition, the grape stalk extracts affected sensory attributes, increasing the scores related to fruity and floral. The effect of addition of grape stalks on the color and phenolic content in red wine was evaluated also by Pascual et al. [61]. The use of grape stalks increased the concentration of catechins, gallocatechins, and proanthocyanidins but led to a decrease in the intensity of color and an increase in the astringency and bitterness of wine. Other authors also reported that the volatile and phenolic composition may also be influenced by the addition 
of vine shoots. Cebrián-Tarancón et al. [62,63], in fact, studied the chemical composition of model [62] and real wines [63] after the use of toasted and not toasted vine shoots, in different particle sizes and at different maceration times. Positive effects were reported especially after 35 days of maceration and using toasted vine shoots at the concentration of $12 \mathrm{~g} / \mathrm{L}$, obtaining wines with high levels of vanillin, trans caftaric acid, caffeic acid, and trans resveratrol. Overall, the ability to preserve the quality of wines and to contribute to the sustainability of the wine chain allows these by-products to be used as an alternative to the classic wine additives in order to improve the phenolic profile despite slight negative effects on color and astringency of wines.

\subsection{Substitution of Bentonite in Winemaking}

The possibility of replacing bentonite with dried and ground grape stalks, was considered by Kosińska-Cagnazzo et al. [64], with the aim of removing the unstable proteins that cause turbidity in wines. The addition of $10 \mathrm{mg} / \mathrm{mL}$ in a wine model precipitated all the proteins, preserved the total polyphenols content, but caused a change in color of wine at high doses. The quantity of proteins remaining in wine, in fact, was inversely proportional to the addition of grape stalks, due to the interactions between proteins and polyphenols that promote the formation of precipitates. This could be exploited, for example, in white wine rich in insoluble proteins that precipitate slowly and poor in tannins useful for the initial protein precipitation.

\subsection{Production of High-Added Value Foods}

As a result of the growing global interest in the relationship between nutrition and health, recent studies focused on the development of innovative food products [70,87]. Some researchers have analyzed the possibility of integrating agro-food by-products to produce foods improved by a nutritional point of view.

For this purpose, Borges et al. [70] added wine lees to produce cereal bars. Wine lees represent a precious by-product linked to the presence of insoluble carbohydrates (from cellulosic and hemicellulosic fractions), phenolic compounds, and lignin, but especially proteins, which make wine lees nutritionally very rich $[70,73]$.

To increase the nutritional value of the bars, the authors used wine lees subjected to an autolysis process to break the yeast cell walls to facilitate the release of accumulated proteins inside. The results showed that the addition of this by-product at 2.5 and $5 \%$ allows cereal bars to be obtained that contribute to the recommended daily protein intake; from a sensory point of view, instead, the addition of wine lees made the sample darker but acceptable to the taste by consumers without finding substantial differences compared to unfortified cereal bars.

The impact of adding wine lees to ice cream production was assessed by Hwang et al. [71] through the addition of 50, 100, and $150 \mathrm{~g} / \mathrm{kg}$ of wine lees homogenized with distilled water. The results showed that the addition of $50 \mathrm{~g} / \mathrm{kg}$ of wine lees improved the characteristics of the ice cream, leading to a decrease in specific gravity, $\mathrm{pH}$, firmness, lightness, and freezable water amount and a concomitant increase in viscosity, melting rate, yellowness, and fat destabilization. In addition, the fortified product showed higher antioxidant activity, confirming that the compounds present in wine lees were stable during the production process. However, the addition at higher amounts determined a negative effect related to the increase of the particle size of fat globules and overrun (the amount of air incorporated during the batch freezing). Pundhir et al. [72], instead, added $35 \mathrm{~g} / \mathrm{kg}$ of wine lees to produce a fortified ice cream with low sugar content. The product showed an increased phenolic content with improved physical, functional, and rheological properties, while a decrease in $\mathrm{pH}$, specific weight, and overrun due to increased viscosity and an increase in the destabilization index of fats were also observed. The sensory analysis showed a higher color intensity and overall pleasantness than control without extract, as also found by Sharma et al. [73]. 
Microbiological aspects related to the addition of wine lees in ice cream were investigated by Ayar et al. [74], who evaluated the vitality of Lactobacillus acidophilus (ATCC 4357D-5) and Bifidobacterium animalis subsp. lactis (ATCC 27536) after 1, 15, 30, and 60 days of storage. The presence of dietary fiber from wine lees had a positive effect on the survival of L. acidophilus during storage, but slightly decreased the count of $B$. animalis subsp. lactis whose decrease was less than $1.0 \mathrm{log}$ colony-forming unit (CFU)/g, however, showing concentrations greater than $6 \log \mathrm{CFU} / \mathrm{g}$, such as to define ice cream as a probiotic (European Communities (EC) Regulation No 1924/2006). Moreover, the addition of wine lees improved the physico-chemical and sensory characteristics, as described in previous studies.

Wine lees have also been tested as preservatives to replace the most commonly used additives in meat products. This kind of food tends to oxidize rapidly during storage, so Alaracon et al. [75] estimated the effect of adding wine lees at 2.5 and $5 \%$ in deer burgers packaged in modified atmosphere at $4{ }^{\circ} \mathrm{C}$. The fortification countered lipid and protein oxidation due to increased phenolic content and antioxidant activity. Moreover, the addition of wine lees had an antimicrobial effect against psychotrophic aerobic bacteria and modified the organoleptic characteristics of the products. After sensorial analysis, in fact, the hamburgers had attributes like wine and bakery notes, considered pleasant at low intensity, due to the increase of benzene compounds, esters, and acids present initially in wine lees. The addition of lees preserved the typical color of meat, with a low decrease in values of redness $\left(\mathrm{a}^{*}\right)$ compared to the control samples.

\subsection{Improvement of Alcoholic Beverage Quality}

Wine quality is an essential element for the marketability of the product, which depends on both oenological and cultivation techniques. In recent years, attention to sustainability of production in general and viticulture has become an increasingly topical requirement. For these reasons, researchers paid attention to finding alternatives to traditional fertilizers. Currently, aqueous oak extracts are used, because the compounds present are assimilated by the grape and transmitted in the wine, influencing both quality and composition [88]. Sánchez-Gómez et al. [65] studied the chemical composition of aqueous extracts of toasted and untoasted vine shoots, highlighting an interesting composition in terms of phenolic, volatile, and mineral compounds, that if assimilated by plants by foliar applications, could improve the amino-acid, volatile, and phenolic composition of wines obtained.

The aqueous formulations were utilized for foliar treatments, on the seventh day postveraison, comparing the results with the effect of the treatment with water and adjuvants. The use of this innovative fertilizer allowed an improvement in the volatile composition of wines to be obtained, probably due to the increasing amino acid content. Some amino acids, in fact, such as phenylalanine, leucine, isoleucine, and valine are precursors of volatile compounds important in wine [89,90]. In other studies, Sánchez-Gómez et al. [32,66] tested the effect of two different extracts of vine shoots, one deriving from untoasted and the other from toasted vine shoots, by applying them on the leaves at veraison. Both extracts improved the classic parameters such as $\mathrm{pH}$, total and volatile acidity, and color and positively influenced phenolic and volatile composition of the wine. In addition, the foliar treatment increased grape yield, expressed as $\mathrm{kg} /$ plant, and induced a decrease in the alcohol content of the wine. In fact, treated plants had grapes with a lower ${ }^{\circ}$ Brix than control ones, probably due to a stress reaction induced by the use of extracts, which led to decrease of the photosynthesis process and consequently of sugar concentration. Sánchez-Gómez et al. [32] also characterized the floral and fruity descriptors of wines, finding higher spicy notes due to the presence of compounds such as norisoprenoids ( $\beta$-damascenone), vanillin derivatives, guaiacol, and syringol, as well as an increase in the content of stilbenes, especially when the vine shoots were toasted. In another study, Sánchez-Gómez et al. [67] carried out foliar applications with vine shoot extracts in order to evaluate the concentration of phenolic compounds and glutathione in the must and 
wine, as well as the color of white wines, which very often tends to be modified due to oxidation. In this context, glutathione plays a key role in giving origins to compounds capable of inhibiting the browning of wines. The results showed that the foliar application with vine shoot extracts did not influence the concentration of glutathione compared to other treatments that otherwise decrease it, obtaining an overall improvement in the color of the wines produced.

The quality of the wine was also improved by Miljić et al. [68] by adding grape seeds and stalks during the vinification in red. The presence of stalks increased the phenolic content and antioxidant activity compared to control wines; however, the experimental wine showed pronounced herbal notes, which reduced consumer acceptability when $50 \%$ of grape stalks were used, unlike the addition of $25 \%$, which improved sensory characteristics and increased acceptability.

An innovative liqueur obtained from red fruit and fortified with grape stalks, was produced by Barros et al. [69], who used this by-product as a source of polyphenols. The liqueur was obtained by adding $50 \mathrm{~g}$ of grape stalk powder in marc grape spirits and sugar, subjected to a maceration phase, and analyzed after 90 and 180 days. The product obtained had a higher antioxidant activity due to the presence of bioactive compounds (ortho-diphenols, flavanols, flavonols, and anthocyanins) compared to a liqueur obtained without the addition of grape stalks. The highest value of antioxidant activity was achieved after 90 days of maceration, also showing a change in color parameters. The value of lightness $\left(\mathrm{L}^{*}\right)$ decreased due to the precipitation of particles of plant material that increased turbidity; the values of redness $\left(\mathrm{a}^{*}\right)$ and yellowness $\left(\mathrm{b}^{*}\right)$ instead increased, obtaining an innovative liqueur with an attractive color.

\subsection{Inhibition of Food Pathogens}

The inhibiting effect of grape stalk polyphenols was assayed against the growth of some food pathogens, such as Listeria monocytogenes, Staphylococcus aureus, Salmonella enterica subsp. enterica serovar Typhimurium, and Escherichia coli O157: H7. As an alternative to synthetic antimicrobials, grape stalk extracts were applied on samples of fresh leafy vegetables (lettuce and spinach). The results related to antimicrobial activity of extract showed a high inhibition efficacy at a concentration of $25 \mathrm{~g} / \mathrm{L}$, especially against $E$. coli O157: H7 and Salmonella enterica, showing a reduction of about 2 logarithmic units [76]

In a subsequent study, Vázquez-Armenta et al. [77] evaluated the effect of grape stalks extracts, compared to synthetic disinfectants, on motility, surface energy, and adhesion of Listeria monocytogenes on food contact surfaces, such as stainless steel and polypropylene. The results obtained after the use of 18 and $20 \mathrm{mg} / \mathrm{mL}$ of grape stalk extracts on both surfaces showed a greater reduction in pathogen adhesion than the control; the presence of grape stalk extracts probably induced the synthesis of exopolysaccharides, which is responsible for the inhibition of motility, adhesion, and biofilm formation. In addition, a greater impact of phenolic compounds such as ferulic, gallic, and caffeic acid, compared to flavonoids such as catechin and rutin, on the inhibition of Listeria monocytogenes, was shown. The in vitro antimicrobial activity of grape stalks after 64 days of storage against positive and negative Gram bacteria was studied by Gouvinhas et al. [49]. In particular, antimicrobial activity was tested against Listeria monocytogenes, Staphylococcus aureus, Enterococcus faecalis, Pseudomonas aeruginosa, Escherichia coli, and Klebsiella pneumoniae, which are known as foodborne pathogens. The high phenolic content, in particular ortho-diphenols and flavonoids, allows, therefore, the extracts to be used as antimicrobials for the high inhibitory power shown, in some cases, to be greater than commercial antimicrobials.

\section{Food Packaging Formulations}

In recent years, the massive use of plastic materials has inevitably led to an increase in issues related to environmental pollution and the disposal of these materials [91]. To tackle this problem, interest in sustainable packaging made with biopolymers from renewable agro-industrial sources, widely available and cheap, is growing [92-94]. In Table 2 are 
reported the possible applications of vine and winery by-products as fillers for food packaging.

In order to find a substitute for expanded polystyrene (EPS) in the trays, Engel et al. [91] added $18.4 \%(w / w)$ of grape stalks, known for their richness in lignocellulosic fibers, and glycerol (as plasticizer) to the polymer fraction (cassava starch-based foams). This increased the tensile strength and elasticity of starch-based foams through the interfacial interaction that occurs between the matrix and the fibers, obtaining foams with good mechanical properties, low density, and increased moisture resistance and hydrophobicity. In a subsequent study, the same authors carried out tests of applicability on low moisture foods (cake) of biodegradability of polymer matrix added with $7 \%(w / w)$ of grape stalks [95]. The applicability tests on foods, compared to the use of expanded polystyrene (control), highlighted the appearance of deformations in correspondence of the contact points between cake and packaging and the increase in moisture in the first days of storage; however, after nine days of storage the samples showed no significant difference in moisture content. These results showed a possible use of the innovative packaging for foods with low moisture content as an alternative to expanded polystyrene materials for short-term storage. The study on biodegradability, instead, showed that the amorphous structure of the innovative packaging contributes to rapid biodegradation, which is useful for reducing environmental problems and for the disposal of waste and by-products.

El Achaby et al. [96] studied the possibility of producing cellulose nanocrystals (CNCs) from vine shoots composed of about $70 \%$ holocellulose (cellulose and hemicellulose) and $20 \%$ lignin. After extraction, the CNCs were added in amounts of 1, 3, 5, and $8 \%$ $(w / w)$ as reinforcements for the production of materials with carboxymethyl cellulose as a biopolymer matrix. The mechanical properties of the obtained material highlighted a final structure with a high crystallinity $(82 \%)$ and thermal stability, and good colloidal stability in water, thus obtaining a biopolymer with good properties of elasticity and tensile strength.

Vine shoots were further applied as fillers of a matrix of poly(3-hydroxybutyrate-3hydroxy-valerate) (PHBV) by adding $20 \%(w / w)$ of grounded vine shoots [97]. As a result, an acceleration of the biodegradation kinetics of the material in the soil, as well as packaging with good structure and morphology properties, were found. Nanni et al. [98,99], in two subsequent studies, tested the use of wine lees as fillers at 10, 20, and $40 \mathrm{phr}$ (parts for hundred parts of polymer) in biodegradable biopolymers, such as poly(3-hydroxybutyratecohydroxyhexanoate) (PHBH), poly(3-hydroxybutyrate-cohydroxyvalerate) (PHBV), and polybutylene succinate (PBS). The obtained results on tensile and creep tests, scanning electron microscopy, and differential scanning calorimetry seemed to be promising. In fact, the addition of wine lees increased the Young's modulus without decreasing the tensile strength due to the good adhesion between wine lees particles and the matrix. 
Table 2. Applications of wine by-products as filler to improve food packaging.

\begin{tabular}{|c|c|c|c|c|c|}
\hline Matrix & Compounds & Treatments & Source & Result & References \\
\hline Cassava starch-based foams & Lignocellulosic insoluble fibers & Drying and crushing & GS & $\begin{array}{c}\text { Foams with good mechanical properties and increased } \\
\text { moisture resistance. }\end{array}$ & [91] \\
\hline Cassava starch-based foams & Lignocellulosic insoluble fibers & Drying and crushing & GS & $\begin{array}{c}\text { Good mechanical and biodegradable packaging properties } \\
\text { and low moisture resistance. }\end{array}$ & [95] \\
\hline Carboxymethyl cellulose & Cellulose & $\begin{array}{l}\text { Alkali, bleaching, and acid } \\
\text { hydrolysis treatments }\end{array}$ & VS & $\begin{array}{l}\text { Increase of elastic modulus and tensile strength, } \\
\text { crystallinity, and high thermal stability of biopolymer } \\
\text { incorporated with cellulose nanocrystals from vine shoots. }\end{array}$ & [96] \\
\hline PHBV & Lignocellulosic insoluble fibers & Drying and milling & VS & $\begin{array}{l}\text { Complete biodegradation with fillers consisting of vine } \\
\text { shoots are exhausted. }\end{array}$ & [97] \\
\hline $\mathrm{PHBH}$ and $\mathrm{PHBV}$ & Inorganic fractions & Drying and grounding & WL & $\begin{array}{l}\text { Production of biopolymers, such as } \mathrm{PHBH} \text { and PHBV, with } \\
\text { good thermal, mechanical, rheological, and morphological } \\
\text { characteristics. }\end{array}$ & [98] \\
\hline PBS & Inorganic fractions & Air-cooling and grounding & WL & $\begin{array}{l}\text { Production of biopolymers, such as PBS, with good thermal, } \\
\text { mechanical, rheological, and morphological characteristics. }\end{array}$ & [99] \\
\hline
\end{tabular}

PHBV, poly(3-hydroxybutyrate-3-hydroxy-valerate); PHBH, poly(3-hydroxybutyrate-cohydroxyhexanoate); PBS, polybutylene succinate; GS, grape stalks; VS, vine shoots; WL, wine lees. 


\section{Conclusions}

The different researches examined in this review show a growing interest in vine and winery by-products, which are not managed as wastes but as a source of functional compounds to be exploited in the production of innovative food and packaging. The presence of bioactive compounds, such as polyphenols and dietary or lignocellulosic fiber, allows these by-products or their extracts to be used as (i) antioxidant or stabilizing agents, replacing the most used oenological additives; (ii) plant bio-stimulants, obtaining grapes and wines with high quality characteristics; (iii) antimicrobial agents against food pathogens; (iv) phenolic content improvement; and (v) alternatives to petrochemical polymers, ensuring the environmental sustainability. Their valorization, therefore, allows one to give a second life to the winery by-products, contributing at the same time to the reduction of production costs and residual quantity. In fact, national legislation, international regulatory frameworks, and directives concerning waste management indicate waste prevention $/ \mathrm{minimization}$ and by-product valorization as key strategies for the effective management system and sustainability of the food industry.

Author Contributions: Conceptualization, G.D., V.M.P., and F.C.; methodology, M.T., G.D., and F.C.; writing—original draft preparation, M.T., G.D., C.S., and F.C.; writing—review and editing, M.T., G.D., C.S., V.M.P., and F.C.; funding acquisition, F.C. All authors have read and agreed to the published version of the manuscript.

Funding: This research was funded by Ministero dell'Istruzione, dell'Università e della RicercaProgrammi di Ricerca 2017 (2017JTNK78) “GOOD-BY-WASTE. Obtain GOOD products—exploit BY-products-reduce WASTE” (CUP H98D19000940006).

Institutional Review Board Statement: Not applicable.

Informed Consent Statement: Not applicable.

Conflicts of Interest: The authors declare no conflict of interest.

\section{References}

1. OIV. The International Organisation of Vine and Wine, 2019. Statistical Report on World Vitiviniculture. Available online: http:/ / oiv.int/public/medias/6782/oiv-2019-statistical-report-on-world-vitiviniculture.pdf (accessed on 18 December 2020).

2. Prozil, S.O.; Evtuguin, D.V.; Lopes, L.P.C. Chemical composition of grape stalks of Vitis vinifera L. from red grape pomaces. Ind. Crop. Prod. 2012, 35, 178-184. [CrossRef]

3. Barba, F.J.; Zhu, Z.; Koubaa, M.; Sant'Ana, A.S.; Orlien, V. Green alternative methods for the extraction of antioxidant bioactive compounds from winery wastes and by-products: A review. Trends Food Sci. Technol. 2016, 49, 96-109. [CrossRef]

4. Beres, C.; Freitas, S.P.; Godoy, R.L.; de Oliveira, D.C.R.; Deliza, R.; Iacomini, M.; Mellinger-Silva, C.; Cabral, L.M.C. Antioxidant dietary fibre from grape pomace flour or extract: Does it make any difference on the nutritional and functional value? J. Funct. Foods 2019, 56, 276-285. [CrossRef]

5. OIV. The International Organisation of Vine and Wine, 2020. Statistical Report on World Vitiviniculture. Available online: http: //www.oiv.int/js/lib/pdfjs/web/viewer.html?file=/public/medias/7545/it-produzione-di-vino-2020-prime-stime-oiv.pdf (accessed on 18 December 2020).

6. Bustamante, M.A.; Moral, R.; Paredes, C.; Pérez-Espinosa, A.; Moreno-Caselles, J.; Pérez-Murcia, M.D. Agrochemical characterisation of the solid by-products and residues from the winery and distillery industry. Waste Manag. 2008, 28, 372-380. [CrossRef] [PubMed]

7. Rondeau, P.; Gambier, F.; Jolibert, F.; Brosse, N. Compositions and chemical variability of grape pomaces from French vineyard. Ind. Crop. Prod. 2013, 43, 251-254. [CrossRef]

8. Bordiga, M.; Travaglia, F.; Locatelli, M.; Arlorio, M.; Coïsson, J.D. Spent grape pomace as a still potential by-product. Int. J. Food Sci. Technol. 2015, 50, 2022-2031. [CrossRef]

9. Dávila, I.; Robles, E.; Egüés, I.; Labidi, J.; Gullón, P. The biorefinery concept for the industrial valorization of grape processing by-products. In Handbook of Grape Processing By-Products; Galanakis, C.M., Ed.; Academic Press: Cambridge, MA, USA, 2017; pp. 29-53. [CrossRef]

10. Beres, C.; Costa, G.N.S.; Cabezudo, I.; da Silva-James, N.K.; Teles, A.S.C.; Cruz, A.P.G.; Mellinger-Silva, C.; Tonon, R.V.; Cabral, L.M.C.; Freitas, S.P. Towards integral utilization of grape pomace from winemaking process: A review. Waste Manag. 2017, 68, 581-594. [CrossRef] [PubMed] 
11. Bordiga, M.; Montella, R.; Travaglia, F.; Arlorio, M.; Coïsson, J.D. Characterization of polyphenolic and oligosaccharidic fractions extracted from grape seeds followed by the evaluation of prebiotic activity related to oligosaccharides. Int. J. Food Sci. Technol. 2019, 54, 1283-1291. [CrossRef]

12. Ahmad, B.; Yadav, V.; Yadav, A.; Rahman, M.U.; Yuan, W.Z.; Li, Z.; Wang, X. Integrated biorefinery approach to valorize winery waste: A review from waste to energy perspectives. Sci. Total Environ. 2020, 719, 137315. [CrossRef]

13. Devesa-Rey, R.; Vecino, X.; Varela-Alende, J.L.; Barral, M.T.; Cruz, J.M.; Moldes, A.B. Valorization of winery waste vs. the costs of not recycling. Waste Manag. 2011, 31, 2327-2335. [CrossRef]

14. Galanakis, C.M. Recovery of high added-value components from food wastes: Conventional, emerging technologies and commercialized applications. Trends Food Sci. Technol. 2012, 26, 68-87. [CrossRef]

15. Kalli, E.; Lappa, I.; Bouchagier, P.; Tarantilis, P.A.; Skotti, E. Novel application and industrial exploitation of winery by-products. Bioresour. Bioprocess. 2018, 5, 46. [CrossRef]

16. Dwyer, K.; Hosseinian, F.; Rod, M.R. The market potential of grape waste alternatives. J. Food Res. 2014, 3, 91-106. [CrossRef]

17. Fontana, A.R.; Antoniolli, A.; Bottini, R. Grape pomace as a sustainable source of bioactive compounds: Extraction, characterization, and biotechnological applications of phenolics. J. Agric. Food Chem. 2013, 61, 8987-9003. [CrossRef]

18. Yu, J.; Ahmedna, M. Functional components of grape pomace: Their composition, biological properties and potential applications. Int. J. Food Sci. Technol. 2013, 48, 221-237. [CrossRef]

19. Muhlack, R.A.; Potumarthi, R.; Jeffery, D.W. Sustainable wineries through waste valorisation: A review of grape marc utilisation for value-added products. Waste Manag. 2018, 72, 99-118. [CrossRef]

20. Bordiga, M.; Travaglia, F.; Locatelli, M. Valorisation of grape pomace: An approach that is increasingly reaching its maturity-A review. J. Food Sci. Technol. 2019, 54, 933-942. [CrossRef]

21. García-Lomillo, J.; González-SanJosé, M.L. Applications of Wine Pomace in the Food Industry: Approaches and Functions. Compr. Rev. Food Sci. Food Saf. 2017, 16, 3-22. [CrossRef] [PubMed]

22. Mattos, G.N.; Tonon, R.V.; Furtado, A.A.L.; Cabral, L.M.C. Grape by-product extracts against microbial proliferation and lipid oxidation: A review. J. Sci. Food Agric. 2017, 97, 1055-1064. [CrossRef] [PubMed]

23. Spigno, G.; Marinoni, L.; Garrido, G.D. State of the art in grape processing by-products. In Handbook of Grape Processing By-Products; Galanakis, C.M., Ed.; Academic Press: Cambridge, MA, USA, 2017; pp. 1-27. [CrossRef]

24. Pintać, D.; Majkić, T.; Torović, L.; Orčić, D.; Beara, I.; Simin, N.; Mimica-Dukić, N.; Lesjak, M. Solvent selection for efficient extraction of bioactive compounds from grape pomace. Ind. Crop. Prod. 2018, 111, 379-390. [CrossRef]

25. Kammerer, D.; Claus, A.; Carle, R.; Schieber, A. Polyphenol screening of pomace from red and white grape varieties (Vitis vinifera L.) by HPLC-DAD-MS/MS. J. Agric. Food Chem. 2004, 52, 4360-4367. [CrossRef]

26. Rodríguez Montealegre, R.; Romero Peces, R.; Chacón Vozmediano, J.L.; Martínez Gascueña, J.; García Romero, E. Phenolic compounds in skins and seeds of ten grape Vitis vinifera varieties grown in a warm climate. J. Food Comp. Anal. 2006, 19, 687-693. [CrossRef]

27. Katalinić, V.; Možina, S.S.; Skroza, D.; Generalić, I.; Abramovič, H.; Miloš, M.; Ljubenkov, I.; Piskernik, S.; Pezo, I.; Terpinc, P.; et al. Polyphenolic profile, antioxidant properties and antimicrobial activity of grape skin extracts of 14 Vitis vinifera varieties grown in Dalmatia (Croatia). Food Chem. 2010, 119, 715-723. [CrossRef]

28. Teixeira, A.; Baenas, N.; Dominguez-Perles, R.; Barros, A.; Rosa, E.; Moreno, D.A.; Garcia-Viguera, C. Natural bioactive compounds from winery by-products as health promoters: A review. Int. J. Mol. Sci. 2014, 15, 15638-15678. [CrossRef]

29. Ping, L.; Brosse, N.; Sannigrahi, P.; Ragauskas, A. Evaluation of grape stalks as a bioresource. Ind. Crop. Prod. 2011, 33, 200-204. [CrossRef]

30. Spigno, G.; Pizzorno, T.; de Faveri, D.M. Cellulose and hemicelluloses recovery from grape stalks. Bioresour. Technol. 2008, 99, 4329-4337. [CrossRef]

31. Dimou, C.; Kopsahelis, N.; Papadaki, A.; Papanikolaou, S.; Kookos, I.K.; Mandala, I.; Koutinas, A.A. Wine lees valorization: Biorefinery development including production of a generic fermentation feedstock employed for poly(3-hydroxybutyrate) synthesis. Food Res. Int. 2015, 73, 81-87. [CrossRef]

32. Sánchez-Gómez, R.; Zalacain, A.; Pardo, F.; Alonso, G.L.; Salinas, M.R. Moscatel vine-shoot extracts as a grapevine biostimulant to enhance wine quality. Food Res. Int. 2017, 98, 40-49. [CrossRef] [PubMed]

33. Joint FAO/WHO Food Standards Programme, Secretariat of the CODEX Alimentarius Commission: CODEX Alimentarius (CODEX) Guidelines on Nutrition Labeling CAC/GL 2-1985. Available online: http:/ /www.fao.org/fao-who-codexalimentarius / sh-proxy / en / ?lnk=1\&url=https \%253A\%252F\%252Fworkspace.fao.org\%252Fsites\%252Fcodex \%252FStandards $\% 252$ FCXG $\%$ 2B2-1985\%252FCXG_002e.pdf (accessed on 18 December 2020).

34. Karakaya, S. Bioavailability of phenolic compounds. Crit. Rev. Food Sci. 2004, 44, 453-464. [CrossRef] [PubMed]

35. Fernández-Mar, M.I.; Mateos, R.; García-Parrilla, M.C.; Puertas, B.; Cantos-Villar, E. Bioactive compounds in wine: Resveratrol, hydroxytyrosol and melatonin: A review. Food Chem. 2012, 130, 797-813. [CrossRef]

36. Vislocky, L.M.; Fernandez, M.L. Biomedical effects of grape products. Nutr. Rev. 2010, 68, 656-670. [CrossRef] [PubMed]

37. Bhise, S.; Kaur, A.; Gandhi, N.; Gupta, R. Antioxidant property and health benefits of grape byproducts. J. Post Harvest Technol. 2014, 2, 1-11.

38. Tolve, R.; Pasini, G.; Vignale, F.; Favati, F.; Simonato, B. Effect of Grape Pomace Addition on the Technological, Sensory, and Nutritional Properties of Durum Wheat Pasta. Foods 2020, 9, 354. [CrossRef] 
39. Anderson, J.W.; Baird, P.; Davis, R.H.; Ferreri, S.; Knudtson, M.; Koraym, A.; Waters, V.; Williams, C.L. Health benefits of dietary fiber. Nutr. Rev. 2009, 67, 188-205. [CrossRef]

40. Tomé-Carneiro, J.; Gonzálvez, M.; Larrosa, M.; García-Almagro, F.J.; Avilés-Plaza, F.; Parra, S.; Yáñez-Gascón, M.J.; Ruiz-Ros, J.A.; García-Conesa, M.T.; Tomás-Barberán, F.A.; et al. Consumption of a grape extract supplement containing resveratrol decreases oxidized LDL and ApoB in patients undergoing primary prevention of cardiovascular disease: A triple-blind, 6-month follow-up, placebo-controlled, randomized trial. Mol. Nutr. Food Res. 2012, 56, 810-821. [CrossRef] [PubMed]

41. Zhu, F.; Du, B.; Zheng, L.; Li, J. Advance on the bioactivity and potential applications of dietary fibre from grape pomace. Food Chem. 2015, 186, 207-212. [CrossRef]

42. Foschia, M.; Peressini, D.; Sensidoni, A.; Brennan, C.S. The effects of dietary fibre addition on the quality of common cereal products. J. Cereal Sci. 2013, 58, 216-227. [CrossRef]

43. Silva, R.F.M.; Pogačnik, L. Polyphenols from food and natural products: Neuroprotection and safety. Antioxidants $2020,9,61$. [CrossRef] [PubMed]

44. Jayaprakasha, G.K.; Selvi, T.; Sakariah, K.K. Antibacterial and antioxidant activities of grape (Vitis vinifera) seed extracts. Food Res. Int. 2003, 36, 117-122. [CrossRef]

45. Nanditha, B.; Prabhasankar, P. Antioxidants in bakery products: A review. Crit. Rev. Food Sci. 2009, 49, 1-27. [CrossRef]

46. Daglia, M. Polyphenols as antimicrobial agents. Curr. Opin. Biotech. 2012, 23, 174-181. [CrossRef]

47. Zhang, H.; Tsao, R. Dietary polyphenols, oxidative stress and antioxidant and anti-inflammatory effects. Curr. Opin. Food Sci. 2016, 8, 33-42. [CrossRef]

48. Wu, T.; Zang, X.; He, M.; Pan, S.; Xu, X. Structure-activity relationship of flavonoids on their anti- Escherichia coli activity and inhibition of DNA gyrase. J. Agric. Food Chem. 2013, 61, 8185-8190. [CrossRef] [PubMed]

49. Gouvinhas, I.; Santos, R.A.; Queiroz, M.; Leal, C.; Saavedra, M.J.; Domínguez-Perles, R.; Rodrigues, M.; Barros, A.I.R.N.A. Monitoring the antioxidant and antimicrobial power of grape (Vitis vinifera L.) stems phenolics over long-term storage. Ind. Crop. Prod. 2018, 126, 83-91. [CrossRef]

50. Özkan, G.; Sagdiç, O.; Baydar, N.G.; Kurumahmutoglu, Z. Antibacterial activities and total phenolic contents of grape pomace extracts. J. Sci. Food Agric. 2004, 84, 1807-1811. [CrossRef]

51. Oliveira, D.A.; Salvador, A.A.; Smânia, A.; Smânia, E.F.A.; Maraschin, M.; Ferreira, S.R.S. Antimicrobial activity and composition profile of grape (Vitis vinifera) pomace extracts obtained by supercritical fluids. J. Biotechnol. 2013, 164, 423-432. [CrossRef]

52. Baydar, N.G.; Sagdic, O.; Ozkan, G.; Cetin, S. Determination of antibacterial effects and total phenolic contents of grape (Vitis vinifera L.) seed extracts. Int. J. Food Sci. Technol. 2006, 41, 799-804. [CrossRef]

53. Butkhup, L.; Chowtivannakul, S.; Gaensakoo, R.; Prathepha, P.; Samappito, S. Study of the phenolic composition of Shiraz red grape cultivar (Vitis vinifera L.) cultivated in Northeastern Thailand and its antioxidant and antimicrobial activity. S. Afr. J. Enol. Vitic. 2010, 31, 89-98. [CrossRef]

54. Lavelli, V.; Torri, L.; Zeppa, G.; Fiori, L.; Spigno, G. Recovery of Winemaking By-Products. Ital. J. Food Sci. 2016, 28 , 542-564. [CrossRef]

55. Ruiz-Moreno, M.J.; Raposo, R.; Cayuela, J.M.; Zafrilla, P.; Piñeiro, Z.; Moreno-Rojas, J.M.; Mulero, J.; Puertas, B.; Giron, F.; Guerrero, R.F.; et al. Valorization of grape stems. Ind. Crop. Prod. 2015, 63, 152-157. [CrossRef]

56. Raposo, R.; Ruiz-Moreno, M.J.; Garde-Cerdán, T.; Puertas, B.; Moreno-Rojas, J.M.; Gonzalo-Diago, A.; Guerrero, R.; Ortíz, V.; Cantos-Villar, E. Grapevine-shoot stilbene extract as a preservative in red wine. Food Chem. 2016, 197, 1102-1111. [CrossRef] [PubMed]

57. Raposo, R.; Chinnici, F.; Ruiz-Moreno, M.J.; Puertas, B.; Cuevas, F.J.; Carbú, M.; Guerrero, R.F.; Ortíz-Somovilla, V.; Moreno-Rojas, J.M.; Cantos-Villar, E. Sulfur free red wines through the use of grapevine shoots: Impact on the wine quality. Food Chem. 2018, 243, 453-460. [CrossRef] [PubMed]

58. Ruiz-Moreno, M.J.; Raposo, R.; Puertas, B.; Cuevas, F.J.; Chinnici, F.; Moreno-Rojas, J.M.; Cantos-Villar, E. Effect of a grapevineshoot waste extract on red wine aromatic properties. J. Sci. Food Agric. 2018, 98, 5606-5615. [CrossRef] [PubMed]

59. Cruz, S.; Raposo, R.; Ruiz-Moreno, M.J.; Garde-Cerdán, T.; Puertas, B.; Gonzalo-Diago, A.; Moreno-Rojas, J.M.; Cantos-Villar, E. Grapevine-shoot stilbene extract as a preservative in white wine. Food Packag. Shelf Life 2018, 18, 164-172. [CrossRef]

60. Marchante, L.; Loarce, L.; Izquierdo-Cañas, P.M.; Alañón, M.E.; García-Romero, E.; Pérez-Coello, M.S.; Díaz-Maroto, M.C. Natural extracts from grape seed and stem by-products in combination with colloidal silver as alternative preservatives to $\mathrm{SO}_{2}$ for white wines: Effects on chemical composition and sensorial properties. Food Res. Int. 2019, 125, 108594. [CrossRef]

61. Pascual, O.; González-Royo, E.; Gil, M.; Gómez-Alonso, S.; García-Romero, E.; Canals, J.M.; Hermosín-Gutíerrez, I.; Zamora, F. Influence of grape seeds and stems on wine composition and astringency. J. Agric. Food Chem. 2016, 64, 6555-6566. [CrossRef]

62. Cebrián-Tarancón, C.; Sánchez-Gómez, R.; Carot, J.M.; Zalacain, A.; Alonso, G.L.; Salinas, M.R. Assessment of vine-shoots in a model wines as enological additives. Food Chem. 2019, 288, 86-95. [CrossRef]

63. Cebrián-Tarancón, C.; Sánchez-Gómez, R.; Cabrita, M.J.; García, R.; Zalacain, A.; Alonso, G.L.; Salinas, M.R. Winemaking with vine-shoots. Modulating the composition of wines by using their own resources. Food Res. Int. 2019, 121, 117-126. [CrossRef]

64. Kosińska-Cagnazzo, A.; Heeger, A.; Udrisard, I.; Mathieu, M.; Bach, B.; Andlauer, W. Phenolic compounds of grape stems and their capacity to precipitate proteins from model wine. J. Food Sci. Technol. 2020, 57, 435-443. [CrossRef] 
65. Sánchez-Gómez, R.; Garde-Cerdán, T.; Zalacain, A.; Garcia, R.; Cabrita, M.J.; Salinas, M.R. Vine-shoot waste aqueous extract applied as foliar fertilizer to grapevines: Effect on amino acids and fermentative volatile content. Food Chem. 2016, 197, 132-140. [CrossRef]

66. Sánchez-Gómez, R.; Zalacain, A.; Pardo, F.; Alonso, G.L.; Salinas, M.R. An innovative use of vine-shoots residues and their "feedback" effect on wine quality. Innov. Food Sci. Emerg. Technol. 2016, 37, 18-26. [CrossRef]

67. Sánchez-Gómez, R.; Pérez-Álvarez, E.P.; Rosario Salinas, M.; Gonzalo-Diago, A.; Zalacain, A.; Garde-Cerdán, T. Effect of vineshoot and oak extract foliar grapevine applications on oenological parameters, phenolic acids and glutathione content of white musts and wines. Oeno. One 2020, 54, 145-156. [CrossRef]

68. Miljić, U.; Puškaš, V.; Vučurović, V.; Razmovski, R. Acceptability of wine produced with an increased content of grape seeds and stems as a functional food. J. Inst. Brew. 2014, 120, 149-154. [CrossRef]

69. Barros, A.; Gouvinhas, I.; Machado, N.; Pinto, J.; Cunha, M.; Rosa, E.; Domínguez-Perles, R. New grape stems-based liqueur: Physicochemical and phytochemical evaluation. Food Chem. 2016, 190, 896-903. [CrossRef] [PubMed]

70. Borges, M.S.; Biz, A.P.; Bertolo, A.P.; Bagatini, L.; Rigo, E.; Cavalheiro, D. Enriched cereal bars with wine fermentation biomass. J. Sci. Food Agric. 2020. [CrossRef] [PubMed]

71. Hwang, J.Y.; Shyu, Y.S.; Hsu, C.K. Grape wine lees improves the rheological and adds antioxidant properties to ice cream. LWT Food Sci. Technol. 2009, 42, 312-318. [CrossRef]

72. Pundhir, A.; Sharma, A.K.; Banerjee, K.; Jogaiah, S.; Somkuwar, R.G. Improvement in functional, rheological and sensory properties of low sugar ice cream by adding fine wine lees. Progress. Hortic. 2018, 50, 118-123. [CrossRef]

73. Sharma, A.K.; Kumar, R.; Azad, Z.R.A.A.; Adsule, P.G. Use of fine wine lees for value addition in ice cream. J. Food Sci. Technol. 2015, 52, 592-596. [CrossRef]

74. Ayar, A.; Siçramaz, H.; Öztürk, S.; Öztürk Yilmaz, S. Probiotic properties of ice creams produced with dietary fibres from by-products of the food industry. Int. J. Dairy Technol. 2018, 71, 174-182. [CrossRef]

75. Alarcón, M.; López-Viñas, M.; Pérez-Coello, M.S.; Díaz-Maroto, M.C.; Alañón, M.E.; Soriano, A. Effect of wine lees as alternative antioxidants on physicochemical and sensorial composition of deer burgers stored during chilled storage. Antioxidants 2020, 9 , 687. [CrossRef]

76. Vázquez-Armenta, F.J; Silva-Espinoza, B.A.; Cruz-Valenzuela, M.R.; González-Aguilar, G.A.; Nazzaro, F.; Fratianni, F.; AyalaZavala, J.F. Antibacterial and antioxidant properties of grape stem extract applied as disinfectant in fresh leafy vegetables. J. Food Sci. Technol. 2017, 54, 3192-3200. [CrossRef]

77. Vazquez-Armenta, F.J.; Bernal-Mercado, A.T.; Lizardi-Mendoza, J.; Silva-Espinoza, B.A.; Cruz-Valenzuela, M.R.; GonzalezAguilar, G.A.; Nazzaro, F.; Fratianni, F.; Ayala-Zavala, J.F. Phenolic extracts from grape stems inhibit Listeria monocytogenes motility and adhesion to food contact surfaces. J. Adhes. Sci. Technol. 2018, 32, 889-907. [CrossRef]

78. Guerrero, R.F.; Cantos-Villar, E. Demonstrating the efficiency of sulphur dioxide replacements in wine: A parameter review. Trends Food Sci. Technol. 2015, 42, 27-43. [CrossRef]

79. Salaha, M.I.; Kallithraka, S.; Marmaras, I.; Koussissi, E.; Tzourou, I. A natural alternative to sulphur dioxide for red wine production: Influence on colour, antioxidant activity and anthocyanin content. J. Food Comp. Anal. 2008, 21, 660-666. [CrossRef]

80. Çetin, E.S.; Altinöz, D.; Tarçan, E.; Göktürk Baydar, N. Chemical composition of grape canes. Ind. Crop. Prod. 2011, 34, 994-998. [CrossRef]

81. Chaher, N.; Arraki, K.; Dillinseger, E.; Temsamani, H.; Bernillon, S.; Pedrot, E.; Delaunay, J.C.; Mérillon, J.M.; Monti, J.P.; Izard, J.C.; et al. Bioactive stilbenes from Vitis vinifera grapevine shoots extracts. J. Sci. Food Agric. 2014, 94, 951-954. [CrossRef]

82. Gorena, T.; Saez, V.; Mardones, C.; Vergara, C.; Winterhalter, P.; von Baer, D. Influence of post-pruning storage on stilbenoid levels in Vitis vinifera L. canes. Food Chem. 2014, 155, 256-263. [CrossRef]

83. Chagas, R.; Ferreira, L.M.; Laia, C.A.T.; Monteiro, S.; Ferreira, R.B. The challenging $\mathrm{SO}_{2}$-mediated chemical build-up of protein aggregates in wines. Food Chem. 2016, 192, 460-469. [CrossRef]

84. Moreira, M.M.; Barroso, M.F.; Porto, J.V.; Ramalhosa, M.J.; Švarc-Gajić, J.; Estevinho, L.; Morais, S.; Delerue-Matos, C. Potential of Portuguese vine shoot wastes as natural resources of bioactive compounds. Sci. Total Environ. 2018, 634, 831-842. [CrossRef] [PubMed]

85. Zwingelstein, M.; Draye, M.; Besombes, J.L.; Piot, C.; Chatel, G. Viticultural wood waste as a source of polyphenols of interest: Opportunities and perspectives through conventional and emerging extraction methods. Waste Manag. 2020, 102, 782-794. [CrossRef]

86. Sánchez-Gómez, R.; Sánchez-Vioque, R.; Santana-Méridas, O.; Martín-Bejerano, M.; Alonso, G.L.; Salinas, M.R.; Zalacain, A. A potential use of vine-shoot wastes: The antioxidant, antifeedant and phytotoxic activities of their aqueous extracts. Ind. Crop. Prod. 2017, 97, 120-127. [CrossRef]

87. Siró, I.; Kápolna, E.; Kápolna, B.; Lugasi, A. Functional food. Product development, marketing and consumer acceptance-A review. Appetite 2008, 51, 456-467. [CrossRef] [PubMed]

88. Pardo-García, A.I.; de La Hoz, K.S.; Zalacain, A.; Alonso, G.L.; Salinas, M.R. Effect of vine foliar treatments on the varietal aroma of Monastrell wines. Food Chem. 2014, 163, 258-266. [CrossRef]

89. Garde-Cerdán, T.; Ancín-Azpilicueta, C. Effect of the addition of different quantities of amino acids to nitrogen-deficient must on the formation of esters, alcohols, and acids during wine alcoholic fermentation. LWT Food Sci. Technol. 2008, 41, 501-510. [CrossRef] 
90. Procopio, S.; Krause, D.; Hofmann, T.; Becker, T. Significant amino acids in aroma compound profiling during yeast fermentation analyzed by PLS regression. LWT Food Sci. Technol. 2013, 51, 423-432. [CrossRef]

91. Engel, J.B.; Ambrosi, A.; Tessaro, I.C. Development of a cassava starch-based foam incorporated with grape stalks using an experimental design. J. Polym. Environ. 2019, 27, 2853-2866. [CrossRef]

92. Davis, G.; Song, J.H. Biodegradable packaging based on raw materials from crops and their impact on waste management. Ind. Crop. Prod. 2006, 23, 147-161. [CrossRef]

93. North, E.J.; Halden, R.U. Plastics and environmental health: The road ahead. Rev. Environ. Health 2013, 28, 1-8. [CrossRef]

94. Difonzo, G.; Troilo, M.; Squeo, G.; Pasqualone, A.; Caponio, F. Functional compounds from olive pomace to obtain high-added value foods-A review. J. Sci. Food Agric. 2021, 101, 15-26. [CrossRef]

95. Engel, J.B.; Ambrosi, A.; Tessaro, I.C. Development of biodegradable starch-based foams incorporated with grape stalks for food packaging. Carbohyd. Polym. 2019, 225, 115234. [CrossRef]

96. el Achaby, M.; el Miri, N.; Hannache, H.; Gmouh, S.; ben youcef, H.; Aboulkas, A. Production of cellulose nanocrystals from vine shoots and their use for the development of nanocomposite materials. Int. J. Biol. Macromol. 2018, 117, 592-600. [CrossRef] [PubMed]

97. David, G.; Michel, J.; Gastaldi, E.; Gontard, N.; Angellier-Coussy, H. How vine shoots as fillers impact the biodegradation of PHBV-based composites. Int. J. Mol. Sci. 2020, 21, 228. [CrossRef] [PubMed]

98. Nanni, A.; Messori, M. Effect of the wine lees wastes as cost-advantage and natural fillers on the thermal and mechanical properties of poly(3-hydroxybutyrate-co-hydroxyhexanoate) (PHBH) and poly(3-hydroxybutyrate-co-hydroxyvalerate) (PHBV). J. Appl. Polym. Sci. 2020, 137, 48869. [CrossRef]

99. Nanni, A.; Messori, M. Thermo-mechanical properties and creep modelling of wine lees filled Polyamide 11 (PA11) and Polybutylene succinate (PBS) bio-composites. Compos. Sci. Technol. 2020, 188, 107974. [CrossRef] 